\title{
XRF Studies for Chemical Composition and Molecular Formula of Jharkhand Bentonite
}

\author{
Arushi Gupta ${ }^{1}$, Vats Amitabh ${ }^{2}$, Babita Kumari ${ }^{3}$, Bivekanand mishra ${ }^{4}$ \\ ${ }^{1}$ (Department of Chemistry, Bhagwant University, Ajmer, Rajasthan, India) \\ ${ }^{2}$ (D.N.S College, Rajoun, Banka, India) \\ ${ }^{3}$ (Mahila College, Godda, Jharkhand, India) \\ ${ }^{4}$ (Dept. of Chemistry, T.M. Bhagalpur University, Bhagalpur, Bihar, India)
}

\begin{abstract}
The present work is an endeavor to study and trace out good quality bentonite having commercial values from the different parts of Jharkhand hills particularly Sahibganj, Dumka, Godda, Deoghar, Lohardagga and Daltaganj. The work involved survey and sample collection of bentonite samples from the region and their analysis using X-Ray Fluorescence (XRF). The XRF analysis of twenty three samples was done to obtain chemical composition, which was then used for derivation of the theoretical molecular formula. XRF technique has been used for the first time for determining the Chemical Composition of bentonite of Jharkhand hills. The analysis indicates that all the samples except one are good quality bentonites.
\end{abstract}

Keywords - Bentonite, Chemical Composition, Jharkhand Bentonite, Theoretical formula

\section{INTRODUCTION}

India is facing the problem of fluoride in ground water and now even in Ganga water. Provisioning of drinking water to vast population of not only this country, but world as a whole, has put a challenge to the chemists. Recent observation of Arushi Gupta [1,2] shows that bentonite of Rajmahal hill may be a suitable alternative for methods of removal of fluoride from water, particularly, potash alum used in the well-established Nalgonda method. It has been observed that the drinking water supplied to the people of Bhagalpur after treatment of Ganga water contains poisonous metal Aluminium causing Cancer and Alzheimer.

Scanty literature [3-9] is available regarding the quantity of vast deposits of Bentonite in hills of Jharkhand. In continuity of the research information available on the Bentonite from Rajmhal hill and their good quality and commercial values, the work has been extended for the survey and sample collection from the different parts of Jharkhand hills particularly to Sahibganj, Dumka, Godda, Deoghar, Lohardagga and Daltaganj for their studies to trace out good quality bentonite having commercial values and their properties for fluoride removal and to use them as an alternative for potash alum in Nalgonda method.

\section{EXPERIMENTAL}

Twenty three samples were collected after thorough survey in the woods of hills of Jharkhand under the team leader Dr. Shashi Shekhar Singh (Geology Department, M.S. College, Bhagalpur) along with team members Dr. Vats Amitabh (Rajoun, Banka) and Dr. Babita Kumari (Mahila College, Godda). The samples were prepared and packed as per the methods reported in literature earlier [10]. X-Ray Fluorescence (XRF) analysis of these samples was done with the help of Philips PW1480 XRF Spectrometer at Sophisticated Analytical Instrument Facility (SAIF), Gauhati University, Guwahati. Chemical Analysis of the Bentonite samples was undertaken by employing the computerized sequential X-Ray Fluorescence Spectrometer. The Philips X-Ray Spectrometer has Rh, Cr-Au X-Ray tube and can identify elements from Fluorine to Uranium. It has two detectors namely Flow Proportional Counter \& Scintillation Counter. For the purpose of analysis of Clay minerals it uses silicate rock, cement, limestone as standard reference material. The chemical composition of the samples under test was analyzed using silicate rock as standard reference material. The composition data obtained were verified by the data obtained by standard methods of literature [11-15]. The chemical composition has been used for derivation of theoretical molecular formula of these samples. The samples were marked AB (Arushi Bentonite) in place of SRHB (Santhal Pargana Rajmahal Bentonite) to distinguish between regions of collection of samples. They are recorded in Table- 1 . The chemical composition data obtained by XRF is presented in Table-2. The percentage composition of the Bentonite of this region is tabulated in Table- 3 . The method of calculation of theoretical formula has been given in Table-4. Theoretical formula of Bentonite of this region has been recorded in Table-5.

\section{RESULT AND DISCUSSION}

On analysis the percentage composition data of Table- 3 , it has been found that high percentage of Silica, even more than sixty percent is present in AB7 (Jashidih), AB2, AB11 (Sahibganj) and AB17 (Dumka) 
and this data is comparatively higher than the data reported for Rajmahal hills Bentonite ${ }^{1}$ and the literature values present in Table-2. Other bentonite samples have lower limit of 50.93 percent and higher limit of 59.87 percent which is comparable with the data for Silica in Rajmahal Bentonite and the literature values for Bentonite of U.S.A, Canada, and some other state of India.

The Silicon Dioxide and Alumina ratio ranges from 1.69 for AB23 to 3.67 for AB7 in comparison with the ratio for Rajmahal Bentonite having this value from 1.07 to 2.0 approximately. Again AB11 has this ratio equal to 6.76 which is abnormally high. For Yellow Stone of U.S.A., this ratio is 3.03 and for California it is 4.60 where as for Barmer sample it is 2.90 but for Bhimbar sample it is 3.0.

Another important constituent of Montmorillonite is Alumina. The percentage composition of Alumina ranges from $17.92(\mathrm{AB} 7)$ to 31.84 (AB23) with exceptional values like 11.34 (AB11) and 14.49 (AB15). Other values of all Bentonite samples of this range $\mathrm{AB} 1, \mathrm{AB} 2, \mathrm{AB} 4, \mathrm{AB} 5, \mathrm{AB} 6, \mathrm{AB} 8, \mathrm{AB} 9, \mathrm{AB} 11, \mathrm{AB} 12, \mathrm{AB} 13$, $\mathrm{AB} 14, \mathrm{AB} 16, \mathrm{AB} 17, \mathrm{AB} 18, \mathrm{AB} 19, \mathrm{AB} 20, \mathrm{AB} 21, \mathrm{AB} 22$ and $\mathrm{AB} 23$ are well comparable with the values for Rajmahal hill Bentonite having Alumina percentage varied from 18.98 to 33.06. These values are also, comparable with the literature values present in Table-2. California sample contains only 12.76 percent of Alumina as compared to AB11 of Sahibganj having 11.34 percent and AB15 of Godda having 14.49 percent.

The higher percent of Silica and lower percent of Alumina in AB11 gives an indication of this sample having less amount of Montmorillonite and may be declared as poor quality Bentonite. The Silicon Dioxide and Alumina Ratio for Bentonite of this range varies from 1.69 to 3.67 for 20 samples of this zone. The abnormal highest value of 6.76 for AB11 confirms our earlier conclusion regarding this sample. Other values reported in the literature are well comparable with the present values/ the values for Bentonite of the world.

The ratio for Aluminium to Ferric Oxide ranges from 2.78 to 7.12 for 18 samples whereas the highest value of 17.30 for $\mathrm{AB} 13$ and 16.92 for $\mathrm{AB} 11$ are seen. The percentage data for $\mathrm{MnO}, \mathrm{MgO}, \mathrm{CaO}, \mathrm{Na}_{2} \mathrm{O}$ and $\mathrm{K}_{2} \mathrm{O}$ are well comparable with literature values of Bentonite of various states of India and other countries. The higher percentage of Titanium Dioxide is 3.41 and 3.81 percent in the sample AB18 and AB19, more than one percent of Titanium Dioxide is present in almost all samples of this region, AB11 is again having only the lowest value of 0.15 percent.

Theoretical and Molecular Formula Of Bentonite Of Jharkhand: Standard and established method of calculation of theoretical formula of literatue $[1,17,18]$ was used for these Bentonites. Method of calculation of theoretical molecular formula of one sample has been recorded in Table-4. Using this method the theoretical molecular formula of other samples have been calculated and represented in Table-5.

The general theoretical structural formula of half unit cell structure of Bentonite may be written as $\left(\mathrm{Si}_{a} \mathrm{Al}_{\mathrm{b}}\right)\left(\mathrm{Al}_{\mathrm{c}} \mathrm{Fe}_{\mathrm{d}} \mathrm{Mg}_{\mathrm{e}}\right) \mathrm{Ca}_{\mathrm{f}} \mathrm{Na}_{\mathrm{g}} \mathrm{K}_{\mathrm{h}} \mathrm{O}_{10}(\mathrm{OH})_{2}$. The value for $\mathrm{a}, \mathrm{b}, \mathrm{c}, \mathrm{d}, \mathrm{e}, \mathrm{f}, \mathrm{g}, \mathrm{h}$ are tabulated in Table-5. While calculating the theoretical molecular formula of Bentonite, the percentage of Titanium Dioxide was not taken into consideration as, the main constituent of Bentonite is Montmorillonite, and Titanium Dioxide is not the constituent part of Montmorillonite $[10,14]$. The formula of Rajmahal bentonite has been reported in literature ${ }^{1}$ and compared with the formula reported here. The structural formula of Rajmahal bentonite is $\left(\mathrm{Si}_{\mathrm{a}} \mathrm{Al}_{\mathrm{b}}\right)^{\mathrm{IV}}\left(\mathrm{Al}_{\mathrm{c}} \mathrm{Fe}_{\mathrm{d}} \mathrm{Mg}_{\mathrm{e}}\right)^{\mathrm{II}} \mathrm{Ca}_{\mathrm{f}} \mathrm{Na}_{\mathrm{g}} \mathrm{K}_{\mathrm{h}} \mathrm{O}_{10}(\mathrm{OH})_{2}$ where $\mathrm{a}=2.57$ to $3.57, \mathrm{~b}=0.42$ to $1.43, \mathrm{c}=1.14$ to $1.67, \mathrm{~d}=0.10$ to $0.56, \mathrm{e}=0.01$ to $0.53, \mathrm{f}=0.03$ to $0.46, \mathrm{~g}=0.12$ to 1.23 and $\mathrm{h}=0.03$ to 0.53 .

The values of a, b, c, d, e, f, g, h for Jharkhand samples are in the range; $\mathrm{a}=3.49$ to $4.77, \mathrm{~b}=0.07$ to $0.9, \mathrm{c}=0.5$ to $1.88, \mathrm{~d}=0.03$ to $0.41, \mathrm{e}=0.005$ to $0.37, \mathrm{f}=0.0007$ to $0.23, \mathrm{~g}=0.14$ to 0.34 and $\mathrm{h}=0.01$ to 0.19 . The maximum value of ' $a$ ' for Jharkhand bentonite is 4.51 which is more than the maximum value of $a=3.57$ for Rajmahal bentonite. However, only five samples AB1, AB2, AB7, AB11 and AB15 have the 'a' value above 4. Balance 18 samples have these values comparable to Rajmahal Bentonite. The combined value of ' $b$ ' and ' $c$ ' for reported sample is 2.39 which is nearly equal to combined value of ' $b$ ' and ' $c$ ' $=3.1$ for Rajmahal bentonite. The value of $\mathrm{e}, \mathrm{f}$ and $\mathrm{h}$ in the present samples, are lesser than the values reported for the Rajmahal bentonite.

\section{Conclusion}

Twenty three samples of bentonite were collected from the different parts of Jharkhand hills after thorough survey, particularly for examining their properties to trace out good quality bentonite having potential of fluoride removal from water, thereby offering a low cost method for provisioning potable water to rural population of Jharkhand region. The XRF analysis was undertaken on the samples to determine their chemical composition and their theoretical molecular formula. The results were compared with the literature values and it has been ascertained that all the samples except one are good quality bentonite. The chemical composition of bentonites of Jharkhand hills is also comparable to that of Rajmahal hills and can be used for defluoridation of water. 


\section{Acknowledgements}

The author expresses gratitude to SAIF Guwahati, Gauhati University for undertaking the requisite analysis in their testing facility and Lt Cdr Ankush Gupta for generous financial assistance.

\section{REFERENCES}

[1] Arushi Gupta, M. Kumar, A.K. Jha, B.K. Mishra, J. Choudhary and Bivekanand Mishra, Chemical Composition and Molecular Formula of Rajmahal Bentonite (Jharkhand) Asian Journal of Chemistry, 23(12), 2011, 5491-5494.

[2] Arushi Gupta, M. Kumar, J. Choudhary and Bivekanand Mishra, TGA and TG studies of Rajmahal Hills Bentonites of Jharkhand in India, Communicated to Journal of Indian Chemical Society, 2013.

[3] H.N. Siddique and D.P. Bahl, Geology of the Bentonite Deposits of Barmer District, Rajasthan, Memoirs of the Geological Survey of India, 96, 1965.

[4] Satyabrat, K Balu and K. T. Thomas, Transformation of naturally occurring interstratified Radioactive Waste, BARC, 1971.

[5] C.S. Raja Rao, Geological Survey of India progress report on Santhal Parganas, Bihar, for the season 1954, Rec Geol. Surv. Ind.,86, 1958, 18-20.

[6] B. Chaliha, Utilization of Indian bentonite in the refining of vegetable oils, Sci. Cult., 21, 1955,161.

[7] S.K. Guha and Sudhir Sen, A study of the physico-chemical properties of Bihar bentonites, Trans. Ind. Ceram. Soc., 20, 1961,7387.

[8] B.M. Bishnui and R. Prasad, Mineralogical nature of some Indian clays. Part II- Clays from Lamehtaghat, Khandagiri, Tinapahar and Hathi-ki-Dhani, Bull. Cent. Glass Ceram. Res Inst., 7, 1960, 11-28.

[9] K.L. Bhola, Bentonite in India, Quart Jour. Geo. Min Met Soc. Ind., 19, 1947, 55-77.

[10] J. Choudhary, PhD thesis, T.M Bhag. Univ., 1985.

[11] S. Ambi, M. Tech. Dissertation, IIT Delhi, 1977.

[12] S. Ambi, N.K. Jha, M.M. Prasad, and Bivekanand Mishra, Study on Montmorillonite from Santhal Pargana district in Bihar, J. Ind. Chem. Soc., 55, 1978, 1077-1079.

[13] N.K. Jha, Bivekanand Mishra, M.M. Prasad, Ind. Courier, 8, 1976, 1.

[14] B.K. Mishra, PhD thesis, T.M. Bhag. Univ., 2001.

[15] S.S. Mishra, PhD thesis, S.K.M. Univ., 2008.

[16] A.K. Jha, PhD thesis, S.K.M. Univ., 2011.

[17] S. Calliere and S. Henin, Mineralogic Des. Agrles (Masson \& Co., 1963).

[18] N.K. Jha, Private Communication, August 1982, Chem. Dept., IIT Delhi.

Table 1 Locations From Where Samples Were Collected

\begin{tabular}{|c|c|c|}
\hline S. No. & Sample No. & Location \\
\hline 1. & $\mathrm{AB} 1$ & Bakudih \\
\hline 2. & $\mathrm{AB} 2$ & Sahibganj \\
\hline 3. & $\mathrm{AB} 3$ & Bakudih \\
\hline 4. & $\mathrm{AB} 4$ & Bakudih \\
\hline 5. & $\mathrm{AB} 5$ & Deoghar \\
\hline 6. & $\mathrm{AB} 6$ & Chitra \\
\hline 7. & $\mathrm{AB} 7$ & Jasidih \\
\hline 8. & $\mathrm{AB} 8$ & Dumka \\
\hline 9. & $\mathrm{AB} 9$ & Goddha \\
\hline 10. & $\mathrm{AB} 10$ & Sahibganj \\
\hline 11. & $\mathrm{AB} 11$ & Sahibganj \\
\hline 12. & $\mathrm{AB} 12$ & Godda \\
\hline 13. & AB 13 & Daltaganj \\
\hline 14. & $\mathrm{AB} 14$ & Daltaganj \\
\hline 15. & AB 15 & Goddha \\
\hline 16. & $\mathrm{AB} 16$ & Goddha \\
\hline 17. & AB 17 & Dumka \\
\hline 18. & $\mathrm{AB} 18$ & Dumka \\
\hline 19. & $\mathrm{AB} 19$ & Dumka \\
\hline 20. & AB 20 & Goddha \\
\hline 21. & $\mathrm{AB} 21$ & Daltaganj \\
\hline 22. & AB 22 & Lohardaga \\
\hline 23. & AB 23 & Dumka \\
\hline
\end{tabular}

TABLE 2 PERCENTAGE COMPOSITION OF BENTONITE FROM LITERATURE

\begin{tabular}{clllllllll}
\hline S No. & Sample & $\mathbf{S i O}_{2}$ & $\mathbf{A l}_{\mathbf{2}} \mathbf{O}_{\mathbf{3}}$ & $\mathbf{F e}_{\mathbf{2}} \mathbf{O}_{\mathbf{3}}$ & $\mathbf{T i O}_{\mathbf{2}}$ & $\mathbf{C a O}$ & $\mathbf{M g O}$ & $\mathbf{K}_{\mathbf{2}} \mathbf{O}$ & $\mathbf{N a}_{\mathbf{2}} \mathbf{O}$ \\
\hline 1. & Harwecha & 47.82 & 15.88 & 9.8 & 1.34 & 2.4 & 2.23 & 0.8 & 2.29 \\
2. & Hati Singh Ki dhani & 50.86 & 20.99 & 7.2 & 1.32 & $\mathrm{Tr}$ & 3.04 & 0.56 & 1.13 \\
3. & AkliGiral & 47.25 & 18.27 & 9.54 & 1.24 & 1.07 & 1.41 & 0.96 & 1.75 \\
4. & AkliThumbliGiral & 57.35 & 16.98 & 7.34 & 1.28 & 1.54 & 1.54 & 1.55 & 1.2 \\
5. & ThumbliAkli & 49.99 & 20.11 & 6.79 & 1.34 & 0.68 & 1.23 & 0.82 & 3.24 \\
6. & Bisala & 46.38 & 25.15 & 8.4 & 1.7 & $\mathrm{Tr}$ & $\mathrm{Tr}$ & 0.56 & 1.46 \\
7. & Bhadres & 45.77 & 19.06 & 12.6 & 2.19 & $\mathrm{Tr}$ & 3.11 & 0.81 & 1.23 \\
8. & Mahwar & 41.12 & 19.58 & 12.6 & 1.74 & 1.16 & 2.46 & 0.8 & 1.16 \\
9. & USA & 59.92 & 19.78 & 2.96 & 2.96 & 0.64 & 1.33 & 0.57 & 2.06 \\
10. & Canada & 53.96 & 15.44 & 1.31 & 1.31 & 0.8 & 6.99 & 0.54 & - \\
11. & Akli & 54.9 & 19.4 & 6.8 & 6.8 & 0.2 & - & 0.9 & 2.1 \\
12. Jammu and Kashmir & 52.4 & 17 & 1.8 & 1.8 & 1.9 & 1.3 & - & 2.51
\end{tabular}




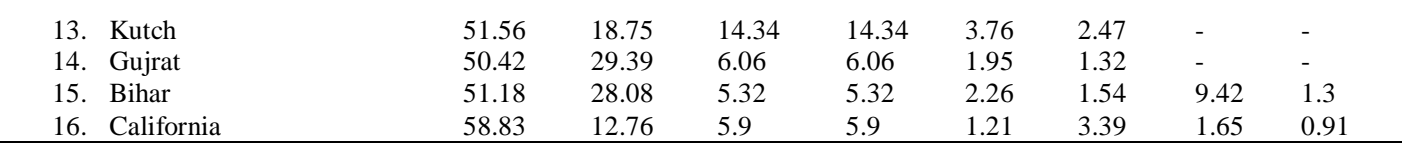

Table 3 Chemical Composition In Percentage Of Bentonite Minerals Of Jharkhand Hills

\begin{tabular}{clcccccccccc}
\hline S No. & $\begin{array}{c}\text { Code } \\
\text { Number }\end{array}$ & $\mathbf{S i O}_{\mathbf{2}}$ & $\mathbf{A l}_{\mathbf{2}} \mathbf{O}_{\mathbf{3}}$ & $\mathbf{F e}_{\mathbf{2}} \mathbf{O}_{\mathbf{3}}$ & $\mathbf{M n O}$ & $\mathbf{M g O}$ & $\mathbf{C a O}$ & $\mathbf{N a}_{\mathbf{2}} \mathbf{O}$ & $\mathbf{K}_{\mathbf{2}} \mathbf{O}$ & $\mathbf{T i O}_{\mathbf{2}}$ & $\mathbf{P}_{\mathbf{2}} \mathbf{O}_{\mathbf{5}}$ \\
\hline 1 & AB1 & 59.87 & 18.92 & 3.45 & 0.03 & 0.33 & 0.61 & 1.17 & 1.68 & 0.51 & 0.25 \\
2 & AB2 & 62.82 & 20.22 & 4.74 & 0.12 & 1 & 0.14 & 1.14 & 2.41 & 1.14 & 0.24 \\
3 & AB3 & 55.54 & 26.02 & 4.14 & 0.01 & 0.43 & 0.32 & 1.11 & 0.58 & 1.42 & 0.04 \\
4 & AB4 & 53.03 & 21.04 & 5.67 & 0.04 & 0.63 & 1.16 & 1.16 & 0.57 & 1.19 & 0.61 \\
5 & AB5 & 56.94 & 24.12 & 5.12 & 0.01 & 0.45 & 0.01 & 1.86 & 1.83 & 1.51 & 0.18 \\
6 & AB6 & 55.67 & 25.29 & 5.75 & 0.01 & 0.88 & 0.32 & 1.24 & 1.13 & 1.38 & 0.08 \\
7 & AB7 & 65.84 & 17.92 & 2.24 & 0.03 & 0.37 & 0.37 & 1.81 & 1.79 & 1.49 & 0.35 \\
8 & AB8 & 57.67 & 26.27 & 5.39 & 0.03 & 0.87 & 1.48 & 1.89 & 0.45 & 1.43 & 0.02 \\
9 & AB9 & 55.62 & 20.86 & 4.72 & 0.025 & 0.35 & 2.45 & 2.15 & 0.25 & 3.04 & 0.11 \\
10 & AB10 & 58.7 & 28.33 & 5.83 & 0.03 & 0.75 & 0.05 & 1.19 & 0.33 & 1.12 & 0.16 \\
11 & AB11 & 76.75 & 11.34 & 0.67 & 0.06 & 0.31 & 0.6 & 1.18 & 0.24 & 0.15 & 0.05 \\
12 & AB12 & 57.24 & 21.22 & 4.91 & 0.049 & 3.19 & 2.65 & 2.17 & 0.25 & 3.25 & 0.12 \\
13 & AB13 & 52.46 & 30.45 & 1.76 & 0.01 & 0.22 & 0.36 & 2.15 & 0.27 & 1.56 & 0.11 \\
14 & AB14 & 55.53 & 24.97 & 4.60 & 0.017 & 0.31 & 2.15 & 2.13 & 0.19 & 2.72 & 0.04 \\
15 & AB15 & 50.93 & 14.49 & 3.35 & 0.022 & 0.19 & 1.17 & 2.17 & 0.18 & 2.39 & 0.03 \\
16 & AB16 & 58.59 & 26.12 & 2.56 & 0.01 & 0.32 & 0.12 & 1.36 & 0.37 & 1.6 & 0.28 \\
17 & AB17 & 60.24 & 22.34 & 4.69 & 0.04 & 0.06 & 1.58 & 1.78 & 0.2 & 1.82 & 0.77 \\
18 & AB18 & 54.17 & 21.28 & 5.71 & 0.048 & 3.68 & 2.37 & 2.16 & 0.18 & 3.41 & 0.11 \\
19 & AB19 & 56.97 & 24.28 & 8.73 & 0.037 & 0.42 & 3.12 & 2.16 & 0.18 & 3.81 & 0.19 \\
20 & AB20 & 56.36 & 21.25 & 5.57 & 0.04 & 0.62 & 1.16 & 2.1 & 0.23 & 1.97 & 0.79 \\
21 & AB21 & 51.48 & 27.09 & 3.8 & 0.02 & 0.57 & 1.43 & 2.1 & 0.24 & 1.7 & 0.19 \\
22 & AB22 & 57.09 & 20.71 & 3.67 & 0.015 & 0.25 & 2.21 & 2.14 & 0.19 & 2.92 & 0.08 \\
23 & AB23 & 54.0 & 31.84 & 2.87 & 0.009 & 0.09 & 0.45 & 2.09 & 0.21 & 2.85 & 0.02 \\
\hline & & & & & & & & & & &
\end{tabular}

TABLE 4 THEORETICAL MOLECULAR FORMULA OF AB1

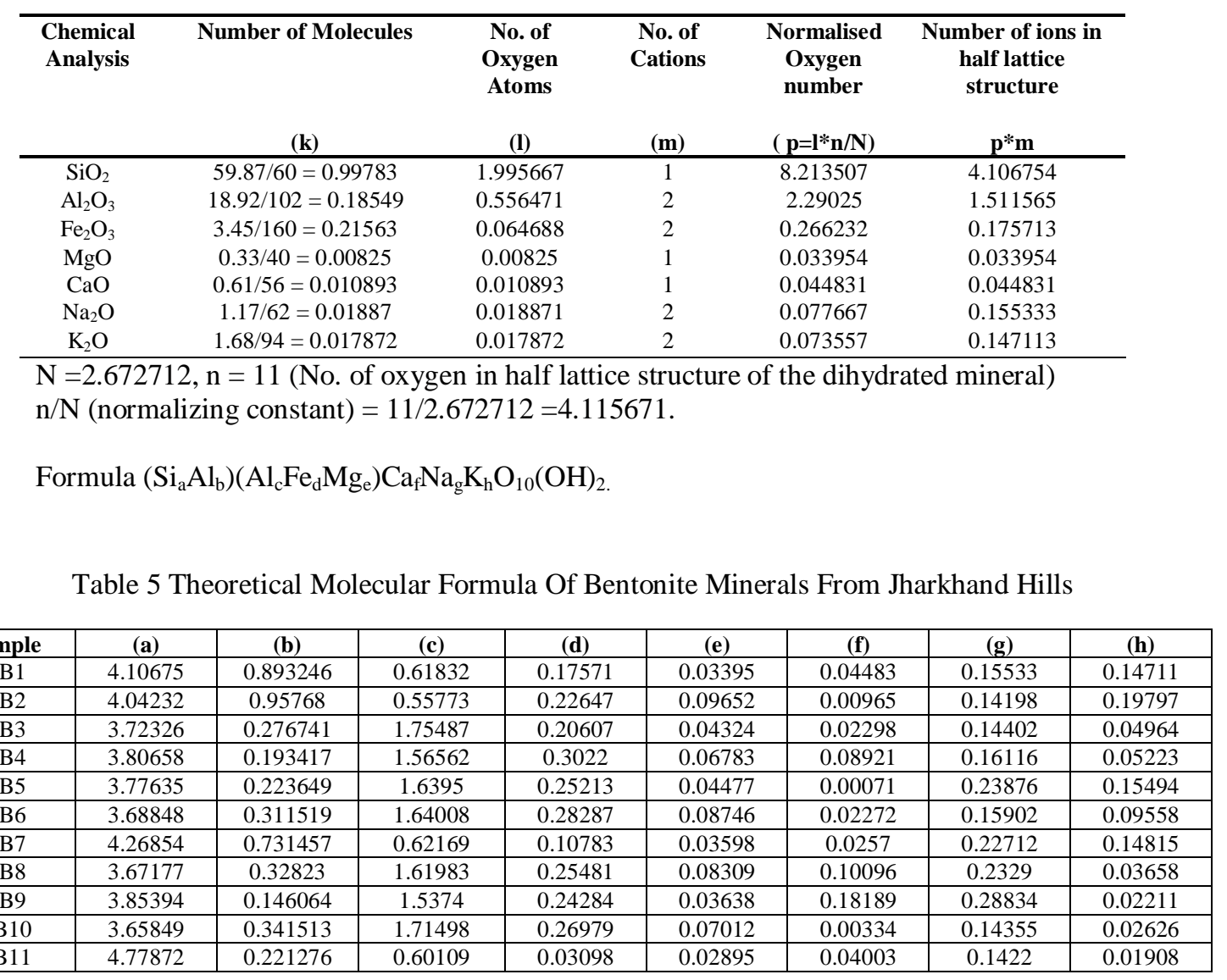


XRF Studies for Chemical Composition and Molecular Formula of Jharkhand Bentonite

\begin{tabular}{|c|c|c|c|c|c|c|c|c|}
\hline $\mathrm{AB} 12$ & 3.76276 & 0.237241 & 1.38744 & 0.23965 & 0.31455 & 0.18665 & 0.27609 & 0.02098 \\
\hline $\mathrm{AB} 13$ & 3.52718 & 0.472825 & 1.9117 & 0.08786 & 0.02219 & 0.02593 & 0.27979 & 0.02318 \\
\hline $\mathrm{AB} 14$ & 3.69638 & 0.30362 & 1.63228 & 0.22735 & 0.03095 & 0.15334 & 0.27442 & 0.01615 \\
\hline $\mathrm{AB} 15$ & 4.1513 & 0.848697 & 0.52691 & 0.20275 & 0.02323 & 0.10218 & 0.34234 & 0.01873 \\
\hline $\mathrm{AB} 16$ & 3.82907 & 0.17093 & 1.81727 & 0.12422 & 0.03137 & 0.0084 & 0.17203 & 0.03087 \\
\hline $\mathrm{AB} 17$ & 3.92529 & 0.074707 & 1.62075 & 0.22691 & 0.00586 & 0.11031 & 0.22449 & 0.01664 \\
\hline $\mathrm{AB} 18$ & 3.66506 & 0.334939 & 1.34197 & 0.28685 & 0.37348 & 0.1718 & 0.28286 & 0.01555 \\
\hline $\mathrm{AB} 19$ & 3.62011 & 0.379886 & 1.41709 & 0.4119 & 0.04003 & 0.23284 & 0.26566 & 0.0146 \\
\hline $\mathrm{AB} 20$ & 3.85456 & 0.145443 & 1.54725 & 0.28285 & 0.0636 & 0.085 & 0.27798 & 0.02008 \\
\hline $\mathrm{AB} 21$ & 3.54782 & 0.452179 & 1.72227 & 0.19445 & 0.05892 & 0.10559 & 0.28011 & 0.02112 \\
\hline $\mathrm{AB} 22$ & 3.93007 & 0.069926 & 1.59057 & 0.18759 & 0.02582 & 0.163 & 0.28513 & 0.0167 \\
\hline $\mathrm{AB} 23$ & 3.4902 & 0.509798 & 1.88708 & 0.13773 & 0.00873 & 0.03116 & 0.26145 & 0.01733 \\
\hline
\end{tabular}

